\title{
Food intake and energy expenditure of Nigerian female students
}

\author{
By A. H. COLE AND R. F. OGUNGBE \\ Department of Human Nutrition, College of Medicine, University of Ibadan, \\ Ibadan, Nigeria
}

(Received 20 February 1986 - Accepted 24 November 1986)

1. Twenty apparently healthy and normal Nigerian female students, resident at the University of Ibadan campus, were studied for seven consecutive days to assess their food energy intake and energy expenditure during sedentary and physical activities.

2. The mean age (years) of the group was 20.05 (SD 3.44, range 16-29), mean height (m) 1.62 (SD 0.07 , range $1 \cdot 47-1 \cdot 74)$ and body-weight (kg) $51 \cdot 28$ (SD 3.21, range 46-58).

3. The food intake of each subject was obtained by direct weighing, and the energy value determined using a ballistic bomb calorimeter. Daily activities were recorded and the energy cost of representative activities was determined by indirect calorimetry.

4. Activities mainly involved sitting, mean ( $\mathrm{min} / \mathrm{d}$ ) 354 (SD 84, range 253-475). Personal domestic activities took a mean of 162 (SD 73) min/d. Sleeping took a mean of 451 (SD 62) $\mathrm{min} / \mathrm{d}$.

5. The mean energy intake of the group was 8480 (SD 1316) $\mathrm{kJ} / \mathrm{d}$ or 167 (SD 30-6) $\mathrm{kJ} / \mathrm{kg}$ body-weight per $\mathrm{d}$. This value is lower than that recommended by the Food and Agriculture Organization/World Health Organization (FAO/WHO) (1973) as the energy requirement for adult women engaged in light activities $(9205 \mathrm{~kJ} / \mathrm{d})$, but it is higher than the FAO/WHO/United Nations University (UNU) (1985) recommended value of $8326 \mathrm{~kJ}$ $(1990 \mathrm{kcal}) / \mathrm{d}$ for a housewife in an affluent society. It is lower than the recommended intake of $9350 \mathrm{~kJ} / \mathrm{d}$ for rural women in developing countries (FAO/WHO/UNU, 1985).

6. The mean energy expenditure (kJ/d) of the female subjects was 6865 (SD 214, range 6519-7222). Mean energy expenditure was lower than mean energy intake.

7. The energy intake and expenditure values indicated that the subjects participating in the present study were not physically very active. It is suggested, for health reasons, that they might undertake more physical activity.

There have been no studies of energy intake, energy expenditure and energy cost of activities of Nigerian women, in particular female students, using indirect calorimetry. There is no information on their habitual activities. The energy requirements of female students and those of other categories of the Nigerian population are not known.

The Food and Agriculture Organization (FAO) $(1950,1957)$ estimated energy expenditure of $13.4 \mathrm{MJ}(3200 \mathrm{kcal}) / \mathrm{d}$ for the reference man and $9.6 \mathrm{MJ}(2300 \mathrm{kcal}) / \mathrm{d}$ for the reference woman. These values have since been reduced by the FAO/World Health Organization (WHO) (1973) to $12.0 \mathrm{MJ}(3000 \mathrm{kcal}) / \mathrm{d}$ for the reference man and 9.2 $\mathrm{MJ}$ $(2200 \mathrm{kcal}) / \mathrm{d}$ for the reference woman. Recently, the FAO/WHO/United Nations University (UNU) (1985) estimated the energy requirement for a housewife in an affluent society, 25 years of age, weighing $55 \mathrm{~kg}$, to be $8 \cdot 3 \mathrm{MJ}(1990 \mathrm{kcal}) / \mathrm{d}$ and that for a woman in a developing country, 35 years of age, weighing $50 \mathrm{~kg}$, to be $9.34 \mathrm{MJ}(2235 \mathrm{kcal}) / \mathrm{d}$.

Nicol (1949) was among the first in Nigeria to study the energy requirements of Nigerians. He reported a study on the nutrition of Nigerian peasant farmers with special reference to the effect of vitamin A and riboflavin deficiency. He determined the energy and nutrient intakes of typical families, of both sexes, in the Niger State of Nigeria, using tables of representative values from Nicholls (1954) and Platt (1954). Nicol (1956a, $b$ ) also studied the nutrition of the Nigerian children, with particular reference to their energy requirements. The children studied were aged 4-6 years and 10-12 years. However, he did not determine the energy cost of activities. Food composition tables of the FAO (Chatfield 1953 $a, b, 1954$ ) were used to obtain the nutrient contents of the diet. When these tables were insufficient, the United States Department of Agriculture (Leung et al. 1952) and United Kingdom 
Medical Research Council (Platt, 1954) tables were used. Since the nutrient composition of several foodstuffs commonly used in Nigeria was not included in any of these tables, many of the foods were sent to the Government Chemist in London for analysis. Between 1954 and 1957 Nicol (1959) carried out other studies on the energy requirements of Nigerian peasant farmers in various parts of the country. The method adopted for the food intake was individual inventory. FAO tables (Chatfield 1953a, $b, 1954$ ) were used to obtain energy values and nutrient compositions of the diets.

Fox (1953) calculated the daily energy expenditure of Gambian farmers for periods of up to 1 month. The results expressed per head do not indicate the energy expenditure of women and men separately. Ancey (1974), quoted by Bleiberg et al. (1980), reported a study in which the duration of all tasks of a large group of female farmers from different villages was recorded by recall on a 1-year basis.

In Upper Volta, Bleiberg et al. (1980) studied the duration of activities and energy expenditure of female farmers in dry and rainy seasons, using indirect calorimetry for the determination of the energy cost of activities.

Schutz et al. (1980) investigated the energy expenditure of food intake of lactating women in Guatemala using heart rate to monitor the energy expenditure. Norgan et al. (1974) reported the results of a study on energy expenditure of 204 New Guinean adults, and Cole et al. (1977) reported the work on energy utilization of obese and normal-weight clinical patients with different physical activities.

The present study on food intake and energy expenditure was therefore carried out to determine the daily energy intake and expenditure of female adult students and the variation and difference between the results obtained in the study and the FAO/WHO/UNU (1985) report.

The method used for food intake was the individual inventory method, and the energy value of food was determined using a ballistic bomb calorimeter. Energy expenditure determination was carried out according to the method previously described by Cole (1976), and similarly by Durnin \& Brockway (1959) and Davidson et al. (1975).

\section{MATERIALS AND METHODS}

Subjects

Twenty female students were selected at random from Queen Elizabeth Hall, one of the two female halls of residence in the University of Ibadan. They were from different departments and faculties of the University.

Before commencement of the study the purpose and objectives were explained in detail to the subjects and they agreed to participate. Specific instructions were given to them not to alter their habits, routine activities and the patterns of their food intakes.

All the subjects were engaged in similar activities; walking to lecture halls, laboratories and cafeteria; sedentary activities - sitting down listening to lectures; taking notes and having seminar discussions or reading in the library or hall of residence; sitting down listening to music and watching television or having friendly discussions - standing or sitting while performing some personal and domestic activities in the hall of residence. A few of the subjects from the science faculty performed laboratory work as part of their normal routine.

\section{Food intake}

The subjects obtained their meals (breakfast, lunch and supper) from the main cafeteria of the University of Ibadan on each of the seven consecutive days. Very few prepared their own food in the hall of residence. 
In quantity, the main food intake was bulky in substance. Local dishes such as gari, eba, amala, fufu, iyan, yam (Dioscorea esculenta) or rice were accompanied by mixed stews, occasionally with mixed cooked vegetables. Between meals the food intake included snacks such as fruits (fresh banana, pawpaw, oranges, apples or mango), roasted maize grains, roasted groundnut, fried plantain chips, meat and chicken pie or biscuits. Apart from water, the subjects' liquid intake included carbonated mineral drinks.

In Nigeria, especially among the Yorubas of the South-west, the staple food consists of items such as rice, maize flour (eko), cassava (Manihot esculenta) flour (gari) and yam flour (iyan). The accompanying stew can be of three types: (1) the main stew which is prepared with beef or fish, or both, with other ingredients including hot pepper (ata wewe), palm oil or groundnut oil or both, spices (atarodo), onion (alubosa), tomato (tumati); (2) mixed vegetable-leaf stew, which is similar in composition to the main stew and also includes usually African locust bean (iru) and one of the following green vegetable leaves: red or green spinach (sokoyokoto), water leaf (efo-tete, efo gbure) or ceylon spinach; (3) sub-stew, which contains one of the following three foodstuffs: lady's finger (ila), artichoke (ewedu), dika nuts (apon). The kind of stew prepared depended on the nature of the staple food. The previously described foods were mainly eaten at lunch and supper. Breakfast included fried or boiled egg, bread, marmalade, butter and occasionally tea, coffee and milk.

\section{Measurement of food intake}

Before the commencement of the study, the purpose and methods of the investigation were fully explained to each female student in her hall of residence. The subjects were taught how to measure and weigh their food accurately. A Salter balance calibrated up to $10 \mathrm{~kg}$ in $50 \mathrm{~g}$ divisions was supplied to each of the students. Beakers were provided for measuring fluids, and plastic containers for easy weighing of such foods as jam, sugar and butter.

The total daily food intake of each subject was measured for seven consecutive days by the inventory method described by Garry et al. (1959) and Durnin et al. (1957), each item of food being separately weighed and recorded. Plate waste was weighed and subtracted from the original portion of food. The investigators and two female field officers from the Human Nutrition Department, University of Ibadan, visited the hall of residence and the cafeteria once daily, usually at meal times, to ensure accurate recording of food intake and to help with any difficulties.

Apart from food intake in the cafeteria or hall of residence, the weights of snacks (which were usually meat pie, biscuits, sausage rolls, carbonated drinks) bought outside were obtained by buying and weighing similar quantities. Samples of all foodstuffs including snacks consumed by individual subjects were collected in labelled plastic containers for analysis. The determination of moisture content of each sample was carried out and the value obtained was used to calculate the dry weight of each food item. The samples were dried in a vacuum oven and homogenized. The heat of combustion was determined using a ballistic bomb calorimeter (CB-370, Gallenkamp and Co. Ltd, London). The values obtained were used in calculating the energy intake of the subjects.

For snacks such as carbonated drinks, and for jam, butter, sugar and milk, standard values for energy contents were obtained from food composition tables (Haenel, 1979).

\section{Recording of activities}

Diary sheets were completed by each subject to obtain a minute-by-minute record of all daily activities (from getting out of bed in the morning to returning to bed at night). This was done throughout the seven consecutive days of the study. A preliminary study was carried out before the main study to establish the ability of each subject to keep detailed activity records. The information supplied from the recording was classified under the 
following headings: lying down in bed (resting); sitting down and listening to lectures or taking notes; eating; listening to the radio; washing clothes; polishing shoes; cleaning the room or fetching water, etc.; walking and climbing stairs at fast, normal or slow pace. The sum of the expenditures in these activities was obtained for the $7 \mathrm{~d}$ of the study; details of the method have been described previously (Cole, 1976).

\section{Measurement of energy expenditure}

Indirect calorimetry was used to determine the energy cost of activites which were grouped as follows: sitting, standing, walking, lying down awake, climbing stairs, personal domestic necessities and sleeping. The energy cost was determined on four to six selected female students for a period of 10-15 min. Daily energy expenditure was obtained by multiplying the total time spent on each activity by its energy cost.

The respiration-gasmeter of the Max-Planck Institute for Work Physiology, Dortmund, developed in Germany, modified by Müller \& Franz (1952) and manufactured by Gesellschaft für Gerätebau, 46 Dortmund Westfalendamm 267-273, combined with face masks, were used to measure the volume of expired air $\left(\dot{V}_{E}\right)$. The respirometer was calibrated as described by Cole (1976). The face masks were in three different sizes. They were manufactured by Volkseigener Betrieb Kombinat Medizin und Labor Technik, Leipzig. To suit our physiological purpose, the face masks were modified in the workshop of the Central Institute of Nutrition, Academy of Sciences of GDR, Potsdam-Rehbrücke.

The subject breathed through a face mask via a corrugated tube to the respirometer and from thence to an inflatable rubber bag; this was placed inside a plastic sack which was filled with expired air to prevent changes in the gas content of the gas bladder (Rahaman \& Durnin, 1964) before analysis. $\dot{V}_{E}$ and temperature (using the thermometer in the respirometer) of the expired air were recorded. Air pressure was measured using a barometer. The measured gas volume was corrected to standard temperature and pressure and the volume of inspired air was derived from the expired volume and the gas concentrations. The oxygen and carbon dioxide concentrations of the mixed expired gas sampled by the inflatable bag through the respirometer were measured using a paramagnetic $\mathrm{O}_{2}$ analyser (Medical Analyser OM-11, Beckman) and a thermoconductive $\mathrm{CO}_{2}$ analyser (Medical Analyser LB-2, Beckman). Both analysers were calibrated regularly with a certified gas mixture of $\mathrm{O}_{2}$ and $\mathrm{CO}_{2}$ and nitrogen (16:4:80, by vol.).

The protocol of the present study was approved by the Ethical Committee of the College of Medicine, University of Ibadan.

\section{RESULTS}

The mean age of the twenty female students was $20 \cdot 1$ (SD 3.44 ) years, mean body-weight 51.3 (SD 3.21 ) kg and mean height 1.6 (SD 0.07) $\mathrm{m}$. The youngest subject was 16 years old, with a body-weight of $48 \mathrm{~kg}$ and height of $1.64 \mathrm{~m}$. The oldest was 29 years old, weighing $55 \mathrm{~kg}$ and $1.58 \mathrm{~m}$ tall.

\section{Energy intake}

There were variations in the energy intake of the individual subjects (Table 1). The mean energy intake of the subjects for the $7 \mathrm{~d}$ was 8480 (SD 1316) $\mathrm{kJ} / \mathrm{d}$ or 167 (SD 30.6) kJ/kg body-weight per d. The highest energy intake was by subject O.F. 11343 (sD 2063) kJ/d or 218 (SD 40.1) kJ $/ \mathrm{kg}$ body-weight per d. Subject O.T. had the lowest daily energy intake consuming 6125 (SD 1473) kJ/d or $111(\mathrm{SD} \mathrm{6.4)} \mathrm{kJ} / \mathrm{kg}$ body-weight per $\mathrm{d}$. 
Energy intake and expenditure of Nigerian women

Table 1. Mean daily energy intakes of twenty female students of the University of Ibadan, Nigeria

\begin{tabular}{llcc}
\hline \hline Subject & $\begin{array}{c}\text { Body-wt } \\
(\mathrm{kg})\end{array}$ & $\begin{array}{c}\text { Energy } \\
\text { intake } \\
(\mathrm{kJ} / \mathrm{d})\end{array}$ & $\begin{array}{c}\text { Energy } \\
\text { intake } \\
(\mathrm{kJ} / \mathrm{kg} \text { body-wt })\end{array}$ \\
\hline O.L. & 50 & 6623 & 133 \\
E.B. & 58 & 7134 & 123 \\
O.T. & 55 & 6125 & 111 \\
O.S. & 54.5 & 7891 & 145 \\
W.I. & 53 & 8657 & 163 \\
A.T. & 53 & 7351 & 139 \\
S.F. & $53 \cdot 5$ & 8251 & 157 \\
K.K. & 55 & 8678 & 158 \\
O.S. & 52 & 7540 & 145 \\
O.J. & 48 & 8372 & 174 \\
J.E. & 46 & 9569 & 206 \\
O.F. & 52 & 11343 & 218 \\
F.T. & 48 & 9891 & 206 \\
O.A. & 52 & 8468 & 163 \\
O.B. & 49 & 9807 & 200 \\
O.K. & 52 & 10799 & 208 \\
A.Y. & 46 & 8858 & 193 \\
O.O. & 50 & 7736 & 155 \\
M.Y. & 47 & 8523 & 181 \\
A.B. & 51 & 7991 & 157 \\
Mean & $51 \cdot 3$ & 8480 & $167 \cdot 1$ \\
SD & $3 \cdot 21$ & 1316 & $30 \cdot 6$ \\
\hline
\end{tabular}

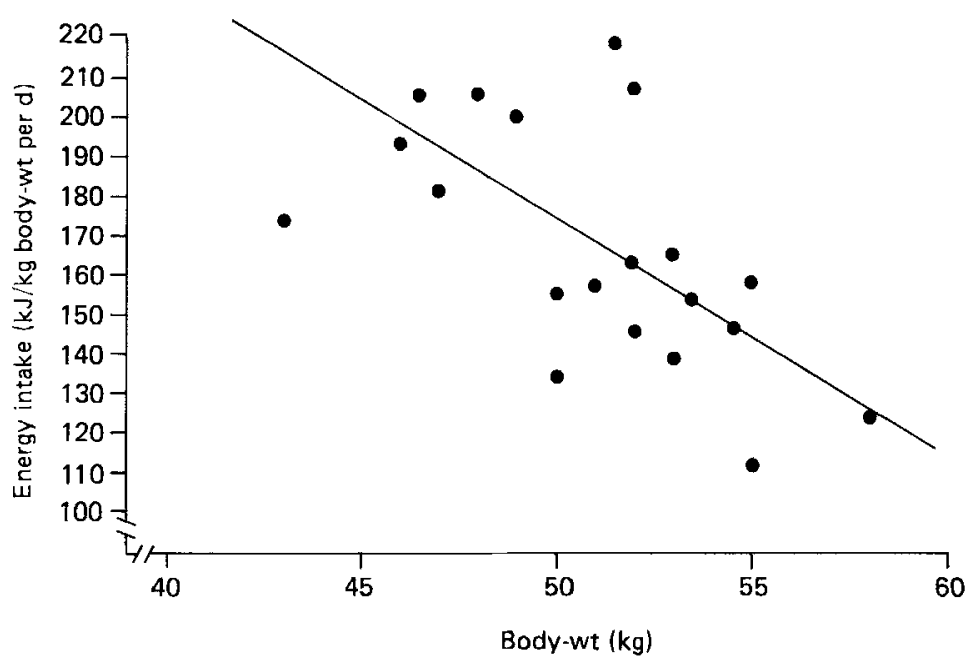

Fig. 1. Scatter diagram of the relation between energy intake $(\mathrm{kJ} / \mathrm{kg}$ body-weight per $\mathrm{d})$ and body-weight $(\mathrm{kg})(r-0.638, P<0.01)$, of twenty female students at the University of Ibadan, Nigeria.

\section{Effect of age and body-weight on energy intake}

There was no significant relation between age and total energy intake $(r 0.096, P>0 \cdot 1)$. There was an inverse relation between energy intake (Fig. 1) expressed as $\mathrm{kJ} / \mathrm{kg}$ body-weight per d $(r-0.638, P<0.01)$. 
Table 2. The mean daily energy balance $(k J)$ of twenty female students at the University of Ibadan, Nigeria

\begin{tabular}{lccc}
\hline \hline Subject & $\begin{array}{c}\text { Energy } \\
\text { intake }\end{array}$ & $\begin{array}{c}\text { Energy } \\
\text { expenditure }\end{array}$ & $\begin{array}{c}\text { Energy } \\
\text { balance }\end{array}$ \\
\hline O. L. & 6623 & 6945 & -322 \\
E.B. & 7134 & 7146 & -12 \\
O.T. & 6125 & 6833 & -708 \\
O.S. & 7891 & 7083 & 835 \\
W.I. & 8657 & 6757 & 1900 \\
S.F. & 8251 & 6753 & 1498 \\
A.B. & 7991 & 6653 & 1338 \\
K.K. & 8678 & 7130 & 1548 \\
O.J. & 8372 & 6736 & 1636 \\
J.E. & 9569 & 6912 & 2657 \\
O.F. & 11343 & 6837 & 4506 \\
F.T. & 9891 & 6862 & 3029 \\
O.A. & 8464 & 7213 & 1255 \\
O.B. & 9807 & 7222 & 2585 \\
O.K. & 10799 & 6519 & 4280 \\
A.Y. & 8858 & 6962 & 1896 \\
O.O. & 7736 & 6761 & 975 \\
M.Y. & 8523 & 6573 & 1950 \\
A.T. & 7351 & 6916 & 435 \\
O.S. & 7540 & 6523 & 1017 \\
\hline \hline
\end{tabular}

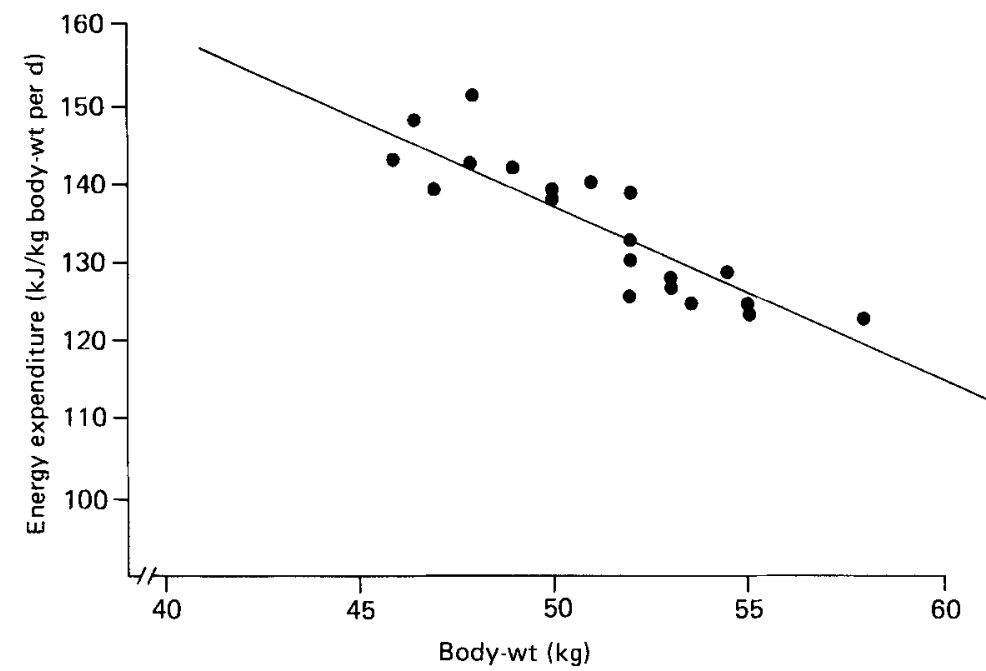

Fig. 2. Scatter diagram of the relation between energy expenditure (kJ/kg body-weight per $\mathrm{d}$ ) and body-weight $(\mathrm{kg})(r-0.877, P>0.01)$, of twenty female students at the University of Ibadan, Nigeria.

\section{Energy expenditure}

The results showed lower energy expenditures than energy intakes (Table 2). The mean expenditure was 6865 (SD 214.0) kJ/d, while the mean energy intake (Table 1) was 8480 $(\mathrm{SD} 1316) \mathrm{kJ} / \mathrm{d}$. The relation between energy intake and energy expenditure was not statistically significant $(P>0.05)$. Seventeen of the twenty students had lower energy expenditures than intakes. For one subject mean energy intake was 7134 (SD 2464) kJ/d or 
Table 3. Average period of time (min) spent on various activities by twenty female students at the University of Ibadan, Nigeria

\begin{tabular}{lccc}
\hline \multicolumn{1}{c}{ Activity } & \multicolumn{2}{c}{$\begin{array}{c}\text { Time period } \\
(\mathrm{min})\end{array}$} & $\begin{array}{c}\text { Percentage } \\
\text { of } \\
\text { 24 h period }\end{array}$ \\
\cline { 2 - 3 } & Mean & SD & 25 \\
Sitting & 354 & 84 & 8 \\
$\quad$ Listening to lectures and & 108 & 58 & $7 \cdot 3$ \\
$\quad$ taking notes & & & $0 \cdot 1$ \\
Walking at normal pace & 105 & 40 & $10 \cdot 0$ \\
Walking fast & 7 & 9 & $11 \cdot 3$ \\
Standing activities & 138 & 70 & $0 \cdot 4$ \\
Personal activities & 162 & 73 & $8 \cdot 0$ \\
Climbing stairs & 5 & 7 & $31 \cdot 3$ \\
Lying down in bed awake & 111 & 53 & 62 \\
Sleeping & 451 & 62 & \\
\hline \hline
\end{tabular}

Table 4. Energy expenditure for various activities of female students of the University of Ibadan, Nigeria

(Mean values and standard deviations)

\begin{tabular}{|c|c|c|c|c|}
\hline \multirow[b]{2}{*}{ Activity } & \multirow{2}{*}{$\begin{array}{l}\text { No. of } \\
\text { subjects }\end{array}$} & \multicolumn{3}{|c|}{ Energy cost $(\mathrm{kJ} / \mathrm{min})$} \\
\hline & & Mean & $\mathrm{SD}$ & Range \\
\hline Sitting & 5 & 3.89 & 0.71 & $3 \cdot 64-4 \cdot 10$ \\
\hline Listening to lectures and taking notes & 6 & $4 \cdot 27$ & 0.34 & $3.89-4.73$ \\
\hline Walking at normal pace & 6 & 7.28 & 1.84 & $4 \cdot 44-9 \cdot 37$ \\
\hline Walking quickly & 4 & 11.67 & 4.18 & $6 \cdot 11-16.28$ \\
\hline Standing & 5 & 6.95 & 1.72 & $5.02-8.58$ \\
\hline Personal necessities & 6 & 6.61 & $1 \cdot 13$ & $5.44-7.91$ \\
\hline Climbing stairs & 6 & $16 \cdot 74$ & 4.77 & $9 \cdot 96-23 \cdot 22$ \\
\hline Lying down in bed awake & 4 & 3.81 & $0 \cdot 13$ & $3.64-3.98$ \\
\hline
\end{tabular}

123 (SD 43) $\mathrm{kJ} / \mathrm{kg}$ body-weight per $\mathrm{d}$ and expenditure $7146 \mathrm{~kJ} / \mathrm{d}$ or $123.2 \mathrm{~kJ} / \mathrm{kg}$ bodyweight per $\mathrm{d}$, while another subject had a higher expenditure $(6945 \mathrm{~kJ} / \mathrm{d}$ or $139 \mathrm{~kJ} / \mathrm{kg}$ body-weight per d) and a lower energy intake $(6623 \mathrm{~kJ} / \mathrm{d}$ or $133.0 \mathrm{~kJ} / \mathrm{kg}$ body-weight per d). Table 2 shows the mean daily energy balance of our female subjects averaged over $7 \mathrm{~d}$. There was no significant relation between body-weight and energy expenditure expressed on a $\mathrm{kJ} / \mathrm{d}$ basis $(r 0.187, P>0.01)$. However, when expressed on a $\mathrm{kJ} / \mathrm{kg}$ body-weight per $\mathrm{d}$ basis, energy expenditure and body-weight were inversely correlated and the relation was statistically significant $(r-0.877, P<0.01$; see Fig. 2$)$.

\section{Activity}

Table 3 shows the mean periods of time spent on various activities. Sleeping involved a mean of $451 \mathrm{~min} / \mathrm{d}(31 \%$ of the $24 \mathrm{~h}$ period), sitting activities $354 \mathrm{~min} / \mathrm{d}(25 \%$ of the $24 \mathrm{~h}$ period), personal necessities $162 \mathrm{~min} / \mathrm{d}(11.3 \%$ of the $24 \mathrm{~h}$ period), while climbing stairs involved the least time $(5 \mathrm{~min} / \mathrm{d}$ or $0.4 \%$ of the $24 \mathrm{~h}$ period). The total time spent by individuals on each activity varied. Subject K. K. spent $497 \mathrm{~min} / \mathrm{d}(35 \%$ of the $24 \mathrm{~h}$ period) on sitting activities and $493 \mathrm{~min} / \mathrm{d}(343 \%$ of $24 \mathrm{~h}$ period) on standing activities. Subject O.F. spent $498 \mathrm{~min} / \mathrm{d}$ sleeping ( $35 \%$ of the $24 \mathrm{~h}$ period) and $235 \mathrm{~min} / \mathrm{d}$ on sitting activities 
( $16 \%$ of the $24 \mathrm{~h}$ period). With subject E. B., more time was spent on personal domestic activities $(572 \mathrm{~min} / \mathrm{d}$ or $40 \%$ of the $24 \mathrm{~h}$ period). The energy cost of each of the nine activities was determined on four to six selected female students. The results are presented in Table 4.

\section{DISCUSSION}

The present study shows substantial variations in individual mean daily energy intake and expenditure. There was also apparently high energy intake but low energy expenditure. Although several investigators have reported low energy intakes among female African farmers (Ghana National Food and Nutrition Board, 1961; Thomson et al. 1966, quoted in Bleiberg et al. 1980), these findings cannot be challenged or substantiated until similar studies are carried out in Nigeria.

A recent report (FAO/WHO/UNU, 1985) estimates the daily energy requirement of a housewife in an affluent society to be $8330 \mathrm{~kJ}(1990 \mathrm{kcal}) / \mathrm{d}$. This value is higher than the mean value obtained in the present study of 6865 (SD 214) kJ/d (1641 (SD 5115) kcal)/d. FAO/WHO/UNU (1985) also estimated the mean daily energy requirement for a reference rural woman in a developing country to be $9360 \mathrm{~kJ}(2236 \mathrm{kcal}) / \mathrm{d}$ which is also higher than the mean intake for our female students. Earlier values such as those reported by the First and Second FAO Committees on Calorie Requirements (FAO, 1950, 1957) estimated energy expenditure to be $9632 \mathrm{~kJ}(2300 \mathrm{kcal}) / \mathrm{d}$ for a reference woman. The estimate was later reduced by the FAO/WHO report on Energy and Protein Requirements (FAO/WHO, $1973)$ and reported to be $9205 \mathrm{~kJ}(2200 \mathrm{kcal}) / \mathrm{d}$ for the reference woman.

\section{Energy intake}

The food intake of the female students was characterized by bulky staples (roots and tubers) with some protein (fish, meat) and vegetable oils (palm oil, etc.). Few snacks were consumed in between the three meals. During the $7 \mathrm{~d}$ study, the pattern of food intake did not differ in terms of food type (contents) or frequency of intake. The observed food habit was rather monotonous, and only slight variations in energy intake were observed. The energy intakes obtained from the present study differed from those of a study of three Sudanese female students in both Cambridge and Khartoum (McCance et al. 1971). The mean daily energy intakes in Cambridge and Khartoum were 8243 and $6828 \mathrm{~kJ}$ (1970 and $1632 \mathrm{kcal})$ respectively, which are lower than the mean intake of $8480 \mathrm{~kJ}(2027 \mathrm{kcal}) / \mathrm{d}$ obtained for female Nigerian University students (present study). However, the number of subjects studied by McCance et al. (1971) was small.

Norgan et al. (1974) studied non-pregnant New Guinean women and reported a mean energy intake of $5938 \mathrm{~kJ}$ (1424 kcal)/d for twenty-nine Kaul women, which is lower than the mean energy intake observed for Nigerian students. However, the mean energy intake of Nigerian students was similar to the mean value of $9029 \mathrm{~kJ}(2158 \mathrm{kcal}) / \mathrm{d}$ obtained for Lufa New Guinean women residing on the highland.

\section{Energy expenditure}

The energy expenditure in the present study was lower than the energy intake. Dema (1967), quoted by Bleiberg et al. (1980), reported a mean daily energy expenditure of $13096 \mathrm{~kJ}$ (3130 kcal)/d for Nigerian women, which is significantly higher than the mean value obtained in the present study $(6865 \mathrm{~kJ}(1641 \mathrm{kcal}) / \mathrm{d})$ and also higher than the mean energy expenditure of $8004 \mathrm{~kJ}(1913 \mathrm{kcal}) / \mathrm{d}$ for three Sudanese female students in Khartoum (McCance et al. 1971).

As there has been no previous assessment of energy expenditure of Nigerian or West African female students, it is not possible to compare the present findings with the results 
from similar surveys. However, the results are compared with information on energy expenditure obtained from women and from female farmers in The Gambia, Upper Volta and New Guinea. It is evident that the values recorded in the present study were slightly lower than values reported by other investigators (Norgan et al. 1974; Bleiberg et al. 1980; Lawrence et al. 1984; FAO/WHO/UNU, 1985). The mean energy expenditure of subjects in the present study was $3.891 \mathrm{~kJ}(0.930 \mathrm{kcal}) / \mathrm{min}, 3.807 \mathrm{~kJ}(0.910 \mathrm{kcal}) / \mathrm{min}$ and $6.950 \mathrm{~kJ}$ $(1.66 \mathrm{kcal}) / \mathrm{min}$ for sitting, lying down and standing activities respectively. Comparative values based on FAO/WHO/UNU (1985) estimates are $5.021 \mathrm{~kJ}(1.2 \mathrm{kcal}) / \mathrm{min}, 5.021 \mathrm{~kJ}$ $(1.2 \mathrm{kcal}) / \mathrm{min}$, and $6.276 \mathrm{~kJ}(1.5 \mathrm{kcal}) / \mathrm{min}$ respectively. The values obtained by Bleiberg et al. (1980) for Upper Volta female farmers and by Norgan et al. (1974) for New Guinean women are quite similar to FAO/WHO/UNU (1985) values, but slightly higher than values obtained in the present study. However, the recorded energy intake and expenditure of individual subjects in the present study are similar to values reported by other investigators (Edholm et al. 1955; Garry et al. 1959; Harries et al. 1962). The observation that female students consumed more food and expended less energy during the study (seven consecutive days) may not reflect their regular pattern of life.

\section{Activity}

In general, the female students spent the greater proportion of their time on activities involving sitting or lying down in bed. It should be noted that Nigerian University female students are not as active in sporting activities as their counterparts in Europe or America. On some occasions, the subjects sat down either reading, eating, watching television or chatting with friends. Although these activities are characteristic of students, it might also be expected that the students should engage themselves in recreational activities which would involve forms of physical exercise which are conducive to cardiovascular, mental and physical fitness.

It was also observed that age did not influence either energy intake or expenditure in the present study. Despite the slight differences in age and body-weight of the subjects, all but three students had a higher energy intake than expenditure. The difference between energy intake and expenditure was high for subjects O.A., O.S. and A.Y. Although these three students reportedly engaged in dancing and jogging, the energy balance did not become negative. The intensity of the activities might not have been as great as anticipated.

The present study is the first study in Nigeria on energy intake and expenditure of Nigerian female students based on indirect calorimetry. Although the present study may not be truly representative of energy expenditure of female students in Nigeria, it is suggested that the study be extended to other groups in Nigeria in order to establish appropriate dietary and energy allowances.

The authors are grateful for partial financial assistence from a Senate Research Grant of the University of Ibadan, Ibadan, Nigeria, and also from the Nestlé Nutrition Research Grant Programme Committee, London under the Chairmanship of Professor J.C. Waterlow. Appreciation is also extended to female students of the University of Ibadan who participated in the study and to Mrs Ejide Akala for her technical assistance.

\section{REFERENCES}

Ancey, G. (1974). Facteurs et Systèmes de Production dans la Société Mossi d'Augourd'hui. MigrationTravail-Terre et Capital. O.R.S.T.O.M. Centre d'Ouagadougou.

Bleiberg, F. M., Brun, T. A. \& Goibhman, S. (1980). British Journal of Nutrition 43, 71-82.

Chatfeld, C. (1949). Food and Agriculture Organization Nutrition Study no. 3. Rome: FAO.

Chatfield, C. (1953a). Food and Agriculture Organization Nutrition Study no. 3. Rome: FAO 
Chatfield, C. (1953b). Food and Agriculture Organization Nutrition Study no. 3, 2nd ed. Rome: FAO.

Chatfield, C. (1954). Food and Agriculture Organization Nutrition Study no. 11. Rome: FAO.

Cole, A. H. (1976). Untersuchungen zum Energieumsatz bei normalgewichtigen und adiposen Personen als Beitrag zum Problem Ernahrung und Leistung und als theoretisch methodische Voraussetzung entsprechender Untesuchungen unter tropischen Bedingungen. Inaugural Dissertation, Akademie der Wissenschaften der DDR, Berlin.

Cole, A. H., Karst, H., Ketz, H. A., Klinger-Mandig, H. \& Mohr, M. (1977). Deutsches Gesundheitswesen 32 , 1517-1522.

Davidson, S., Passmore, R., Brock, J. F. \& Truswell, A. S. (1975). Human Nutrition and Dietetics, 6th ed., pp. 28-30, Edinburgh: Churchill Livingstone.

Durnin, J. V. G. A., Blake, E. C. \& Brockway, J. M. (1957). British Journal of Nutrition 11, 85-94.

Durnin, J. V. G. A. \& Brockway, J. M. (1959). British Journal of Nutrition 13, 41-53.

Edholm, O. G., Fletcher, J. G., Widdowson, E. M. \& McCance, R. A. (1955). British Joumal of Nutrition 9, 286.

Food and Agriculture Organization (1950). First Committee on Calorie Requirement, FAO Nutritional Studies no. 5. Rome: FAO.

Food and Agriculture Organization (1957). Second Committee on Calorie Requirement, FAO Nutritional Studies no. 15. Rome: FAO.

Food and Agriculture Organization/World Health Organization (1973). Energy and Protein Requirements. Technical Report Series no. 522. Geneva: WHO

Food and Agriculture Organization/World Health Organization/United Nations University (1985). Energy and Protein Requirements. Technical Report Series no. 724. Geneva: WHO.

Fox, R. H. (1953). Energy expenditure of Africans engaged in various rural activities. PhD Thesis, University of London.

Garry, R. C., Passmore, R., Warnock, G. M. \& Durnin, J. V. G. A. (1959). Medical Research Council Special Report Series no. 289. London: MRC.

Ghana National Food and Nutrition Board (1961). National Nutrition Survey IV. The Nutrition of Adults in the North. Accra: Ghana National Food and Nutrition Board.

Haenel, H. (1979). Energie und Nahrstoffgehalt von Lebensmitteln. Lebensmitteltabellen. Berlin, DDR: Volkseigener Betrieb Verlag Volk und Gesundheit.

Harries, J. M., Hobson, E. A. \& Hollingsworth, D. F. (1962). Proceedings of the Nutrition Society 21, $157-168$.

Lawrence, M., Singh, J., Lawrence, F. \& Whitehead, R. G. (1984). Nestlé Foundation Annual Report 43-52.

Leung, W. W., Pecot, R. K. \& Watt, B. K. (1952). Agriculture Handbook: United State Department of Agriculture no. 34. Washington, DC: United States Department of Agriculture.

McCance, R. A., Hamad, E. N., Nasr, E. D., Widdowson, E. M., Southgate, D. A., Passmore, R., Shirling, D. \& Wilkinson, M. (1971). Philosophical Transactions of the Royal Society of London 259B, 533-565.

Müller, E. A. \& Franz, H. (1952). Arbeitsphysiologie 14, 499.

Nicol, B. M. (1949). British Journal of Nutrition 3, 25-43.

Nicol, B. M. (1956a). British Journal of Nutrition 10, 181-197.

Nicol, B. M. (1956b). British Journal of Nutrition 10, 275-285.

Nicol, B. M. (1959). British Journal of Nutrition 13, 293-306.

Nicholls, L. (1954). Tropical Nutrition, no. 233.

Norgan, N. G., Ferro-Luzzi, A. \& Durnin, J. V. G. A. (1974). Philosophical Transactions of the Royal Society of London 268 B, 209-348.

Platt, B. S. (1954). Medical Research Council Special Report Series no. 253. London: MRC.

Rahaman, M. M. \& Durnin, J. V. G. A. (1964). Journal of Applied Physiology 19, 1188-1191.

Schutz, Y., Lechtig, A. \& Bradfield, R. B. (1980). American Journal of Clinical Nutrition 33, 892-902. 